This is the final peer-reviewed accepted manuscript of:

Maraldi, T., Prata, C., Marrazzo, P., Hrelia, S., \& Angeloni, C. (2019). Natural Compounds as a Strategy to Optimize "In Vitro" Expansion of Stem Cells. Rejuvenation Research, 23(2), 93-106.

The final published version is available online at: https://doi.org/10.1089/rej.2019.2187

Rights / License:

The terms and conditions for the reuse of this version of the manuscript are specified in the publishing policy. For all terms of use and more information see the publisher's website. 


\title{
Natural Compounds as a Strategy to Optimize "In Vitro" Expansion of Stem Cells
}

\author{
Tullia Maraldi, ${ }^{1}$ Cecilia Prata, ${ }^{2}$ Pasquale Marrazzo, ${ }^{3}$ Silvana Hrelia, ${ }^{3, *}$ and Cristina Angeloni ${ }^{4, *}$
}

\begin{abstract}
The efficient use of stem cells for transplantation is often limited by the relatively low number of stem cells collected. The ex vivo expansion of human stem cells for clinical use is a potentially valuable approach to increase stem cell number. Currently, most of the procedures used to expand stem cells are carried out using a $21 \%$ oxygen concentration, which is about 4 - to 10 -fold greater than the concentration characteristic of their natural niches. Hyperoxia might cause oxidative stress with a deleterious effect on the physiology of cultured stem cells. In this review, we investigate and critically examine the available information on the ability of natural compounds to counteract hyperoxia-induced damage in different types of stem cells ex vivo. In particular, we focused on proliferation and stemness maintenance in an attempt to draw up useful indications to define new culture media with a promoting activity on cell expansion in vitro.
\end{abstract}

Keywords: stem cell expansion, natural compounds, hyperoxia, oxidative stress, cell proliferation, stemness maintenance

\section{Introduction}

$\mathbf{H}$ UMAN STEM CELLS are being investigated for the treatment of many different diseases, like cardiovascular and autoimmune diseases and traumatic lesions. ${ }^{1}$ Among stem cells, particular interest has been focused on mesenchymal stem cells (hMSC) that can be derived from many tissues but are often insufficient to reach a relevant number of cells adequate for clinical use. Moreover, patient age, gender, genetic background, and clinical history influence their quantity and quality.

At present, most procedures to expand stem cells are carried out at an ambient oxygen concentration where cells are exposed to $21 \% \mathrm{O}_{2}$, which is 4 - to 10 -fold greater than the concentration characteristic of their "in vivo" niches. Several studies have demonstrated the deleterious impact of a $21 \%$ oxygen tension on the physiology of stem cells, for example, neuronal stem cells, ${ }^{4}$ bone marrow stem cells, ${ }^{5,6}$ umbilical cord stem cells, ${ }^{7}$ or adipose tissue stem cells. ${ }^{8,9}$ In fact, in vitro culture of MSCs exposed to a $21 \%$ oxygen concentration might increase the production of reactive oxygen species (ROS) and, as a consequence, to be subjected to environmental oxidative stress. In general, ROS, including hydrogen peroxide $\left(\mathrm{H}_{2} \mathrm{O}_{2}\right)$ and superoxide anion $\left(\mathrm{O}_{2}{ }^{-}\right)$, plays crucial roles in stem and progenitor physiology. Nevertheless, the "redox window" hypothesis must be considered: suitable ROS level is vital for physiological cellular functions, ${ }^{10}$ whereas excess ROS contribute to adverse effects on MSCs, including premature senescence, increase of the population doubling time, damages to DNA, ${ }^{11,12}$ and reduced engraftment after transplantation. ${ }^{13}$ Human MSCs are particularly susceptible to early senescence and typically halt proliferation at approximately passage 8 , which limits their expansion potential and therapeutic value. ${ }^{14}$ Another issue to be considered is the need of long-term cryopreservation of stem cells, a routine practice that requires extremely controlled and safe techniques of specimen storage. However, more and more studies are showing contradictory results on the influence of stem cell cryopreservation and thawing, such as wide stresses at physical and biological level, mitochondrial damages, modifications to basal respiration and ATP synthesis, apoptosis and necrosis, shortening of telomeres and cellular senescence, damage to DNA, and oxidative stress. ${ }^{15}$ These results have raised serious alarms concerning the therapeutic effectiveness and safety of stem cells. Ability to

\footnotetext{
${ }^{1}$ Department of Surgery, Medicine, Dentistry and Morphological Sciences, University of Modena and Reggio Emilia, Modena, Italy.

${ }^{2}$ Department of Pharmacy and Biotechnology, Alma Mater Studiorum-University of Bologna, Bologna, Italy.

${ }^{3}$ Department for Life Quality Studies, Alma Mater Studiorum-University of Bologna, Rimini, Italy.

${ }^{4}$ School of Pharmacy, University of Camerino, Camerino, Italy.

*These authors contributed equally to this work.
} 
enhance MSC culture expansion and delay senescence could substantially improve efficacy for autologous stem cell therapy. On these bases, a promising strategy to counteract oxidative stress induced by hyperoxia or by cryopreservation and thawing could be the use of compounds with antioxidant activity. In particular, many natural antioxidant compounds have been demonstrated to counteract oxidative stress by directly scavenging free radicals or activating antioxidant defense pathways. ${ }^{16-18}$ Moreover, the safety of many natural antioxidant compounds has been largely demonstrated ${ }^{19-21}$ and this is an important issue considering that stem cell expansion has principally performed with the intent of implantation.

Another important issue to take into consideration in using natural antioxidant compounds to counteract oxidative stress in stem cells is that these compounds can induce changes in cells that should be checked before using them for treatment. A good antioxidant compound should not impair stem cell stemness, potency, and proliferation. In this review we investigate and critically examine the available information on the ability of natural compounds to counteract hyperoxia-induced damage in different type of stem cells ex vivo. In particular, we focused on proliferation and stemness maintenance in an attempt to draw up useful indications to define new culture media with a promoting activity on cell expansion in vitro.

\section{From the Niche to the Bank}

In living organisms, stem cells reside in a specific microenvironment called niche. Quiescent stem cells are located in the niche until specific signals finish the dormant state and activate the differentiation process. In particular, this dynamic microenvironment accomplishes primarily three functions, thanks to secreted or cell surface molecules: stem cell proliferation control, stem cell daughters fate determination, and protection of stem cells from exhaustion or death. ${ }^{22}$ Not only structural and soluble factors, but also hypoxia plays a crucial role for the stemness maintenance of mesenchymal, embryonic, neural stem, and hematopoietic cells, and could also impact on proliferation and differentiation. ${ }^{23}$

In MSC niches, the local oxygen concentrations fluctuate depending on stem cell type: between $10 \%$ and $15 \% \mathrm{O}_{2}$ in the adipose tissue, ${ }^{24}$ about $1.3 \%$ both in the amniotic fluid and amniotic membrane, ${ }^{22}$ and between $1 \%$ and $7 \% \mathrm{O}_{2}$ in bone marrow. ${ }^{25}$

The bone marrow niche is the most studied in literature. Although bone marrow has a highly complex vascular network, the entire bone interior is relatively hypoxic, with $\mathrm{pO}_{2}$ in the range of $1 \%-4 \% .{ }^{26}$ In general, HSCs stay quiescent in the bone marrow niche, whereas various stimuli that cause loss of quiescence induce strong entry into the cell cycle, and trigger proliferation frequently accompanied by stress, apoptosis, and damage to DNA. ${ }^{27,28}$ Zhou et al. ${ }^{29}$ observed that a low-oxygen niche in bone marrow reduces ROS generation, therefore providing long-term protection against oxidative stress. Ex vivo expansion techniques should promote symmetric stem cell divisions, ${ }^{30}$ and consequently stem cell self-renewal without inducing differentiation and apoptosis.

Indeed, oxygen concentration has a major role in the proliferation and differentiation of stem cells, also in the placenta. It has been demonstrated that cytotrophoblasts proliferate in low-oxygen tension $\left(2 \% \mathrm{O}_{2}\right)$, whereas they differentiate in high-oxygen tension $\left(20 \% \mathrm{O}_{2}\right) .{ }^{31}$ The reduction of oxygen tension below a specific threshold leads to the initiation of a gene expression program by the transcription factor, hypoxia-inducible factor-1 (HIF-1). HIF-1 signaling pathway plays a fundamental role in regulating key processes such as energy metabolism, angiogenesis, cell proliferation, and viability depending on the availability of oxygen in the cell (reviewed in Ref. ${ }^{32}$ ). The low-oxygen tension stabilizes HIF-1, the oxygen-sensitive monomer of the HIF-1, since its ubiquitination and proteasomal degradation are prevented. ${ }^{33,34}$ HIF-1 is linked to transcription of at least 70 genes holding functional hypoxia-responsive element. Most of these genes are involved in cell survival, through the expression of cell surface receptors, angiogenic growth factors, glucose transporters, and glycolytic enzymes. ${ }^{34,35}$ Moreover, under low-oxygen tension stem cell pluripotency is maintained by HIF-2 interaction with the promoter region of OCT4 causing increased transcriptional activity. ${ }^{36}$ OCT4 is the principal regulator of pluripotency in embryonic stem cells (ESCs) and essential to obtain induced pluripotent stem cells (iPSCs) but disappears upon differentiation. ${ }^{37}$

For example, bone marrow HSCs (BHSCs) are quiescent in vivo through conservation of a hypoxic phenotype with high levels of HIF- $1 \alpha$ protein and the hypoxic marker pimonidazole, even when contiguous to arterioles. ${ }^{38}$ Thus, in preserving quiescence into the niche, HSCs must depend on anaerobic glycolysis for energy production. ${ }^{39}$ Indeed, glycolysis is induced by HIF- $1 \alpha$ in response to hypoxia, expressing pyruvate dehydrogenase kinase 1 (PDK1), which inhibits pyruvate dehydrogenase and avoids mitochondrial acetyl-Co-A production and oxidation. The clear result is a metabolic shift that induces glycolysis and decreases ROS generation in hypoxia. Correspondingly, expansion of MSCs in atmospheric oxygen levels upregulates OXPHOS genes and mitochondrial respiration, and accelerates cellular senescence, while hypoxic culture conditions delay senescence. ${ }^{40}$

It is known that the use of $\mathrm{O}_{2}$ in several fundamental metabolic processes by living organisms has got an evolutionary price, as $\mathrm{O}_{2}$ metabolism is the main source of ROS in the cells. The condition known as oxidative stress occurs when the endogenous production of ROS exceeds the cellular capacity of the antioxidant systems. Unfortunately, not always the cellular adaptive processes are able to counteract the accumulation of oxidative damage to key molecules, such as lipids, DNA, and proteins. ${ }^{29}$ While all the cells of an organism might be subjected to the accumulation of damages triggered by oxidative damage, the effects of ROS on stem cells in most self-renewing tissues are of specific interest to the processes of aging and cancer development owing to their undifferentiated condition and longevity of replicative potential. ${ }^{41,42}$

Excessive ROS production leads to the overexpression of the tumor suppressor genes, p21, p53, and p16. ${ }^{43,44} \mathrm{Ac}-$ cordingly, oxidative stress is one of the principal causes of physiological decline during cellular senescence. Forkhead box (Fox) O proteins control ROS generation in stem cells by regulating catalase and SOD expression. ${ }^{45,46}$ It has been observed that the increase of ROS level in FoxO-deficient mice is associated with the disruption of HSC quiescence, increase in HSC apoptosis, and impairment in hematopoietic repopulating abilities. 
In animal models with damaged cellular antioxidant defense system, such as SOD2, an antioxidant enzyme that is present in mitochondria and modulated by FoxO3, a potential correlation between ROS and HSC impairment has been observed. SOD2 evoked a protective activity in mouse neural stem cells (NSCs), and its upregulation improved NSC's survival both in vitro and in vivo. In addition, the alterations related to aging in SOD2 modulation by FoxO3 and DNA damage, recognized by serine/threonine protein kinase ATM (ataxia telangiectasia mutated), contribute to HSC functionality reduction with aging. ${ }^{46} \mathrm{HSC}$ self-renewal capacity relies on ATM-mediated reduction of ROS production as demonstrated by studies carried out in $\mathrm{Atm}^{-/-}$. There is a crosstalk with the ATM-p53 signaling converging on p16 to trigger stem cell senescence. ${ }^{47}$

Other key modulators of aging, oxidative stress, and stem cell functionality are sirtuins (SIRT), a family of NADdependent protein deacetylases. Recently it has been suggested, a role for SIRT1 in maintaining MSC growth and differentiation that have been observed to deteriorate with age. Interestingly, its activation in aged cells protects the cells from p53-dependent apoptosis or senescence. ${ }^{48}$ SIRT3, is crucial in the aged HSCs in the maintenance of mitochondria metabolism and in controlling oxidative stress. Moreover, ectopic upregulation of SIRT3 enhances the function of HSCs during aging by increasing SOD2 antioxidant activity. ${ }^{49}$

On these bases, the aging of stem cells may be controlled by regulating their metabolic and redox state, which in turn might impact on the intracellular accumulation of ROS. The condition defined as "cell culture stress" might induce genetic instability and therefore constitutes a biological risk for cell therapy protocols. These pathways should be reversed or avoided to obtain an efficient stem cell expansion in vitro.

Recently, the increasing interest in the use of MSCs in the clinical practice has led to a high number of studies on the effects of culture conditions and expansion on pathways, behavior, and function of stem cells. As in vivo HSC self-renewal and differentiation are regulated by niche cells secreting cytokines and growth factors, including pleiotrophin, angiopoietin$1,-3$, thrombopoietin, granulocyte colony-stimulating factor, stem cell factor, and Notch ligands, ${ }^{50}$ cytokines were the first drugs studied for HSC ex vivo expansion. Overall, cytokines and their combinations can maintain HSCs and progenitors counteracting apoptosis in in vivo proliferation but leading to a contained human HSCs (hHSCs) expansion. For this reason, further elements are obviously essential for a positive expansion of hHSCs ex vivo.

The impact of oxygen concentration in adult stem cell phenotype, morphology, proliferative capacity, and functionality has been largely investigated with controversial outcomes.

For example, MSCs cultured in low oxygen tension (1\%-10\% oxygen) has revealed enhanced regenerative/reparative properties in animal models of heart, brain, and lung damage. ${ }^{51-53}$

In particular, several studies have shown that human stem cells cultured in a range of $1 \%-5 \%$ of oxygen tensions showed improved cell proliferation and longer lifespan. ${ }^{5,12,54,55} \mathrm{Cul}-$ turing in hypoxia have also been demonstrated to avoid doublestrand breaks (DSB) and chromosomal abnormalities in several types of stem cells. ${ }^{56,57}$ In agreement with this notion, Estrada et al. ${ }^{11}$ showed that, compared with cells grown at $3 \% \mathrm{O}_{2}$, shortterm growth of hMSC at $20 \% \mathrm{O}_{2}$ tension enhances oxidative stress and DNA damage markers, such as DSB, chromosomal aberrations, aneuploidy, and telomere shortening rates. In this study, they showed that expansion at $3 \% \mathrm{O}_{2}$ significantly increases the growth rate of adipose tissue-derived hMSC with a better conservation of telomere length. However, telomerase activity in hMSC was low and insensitive to $\mathrm{O}_{2}$ concentration suggesting that the protection from oxidative stress, due to the growth at $3 \% \mathrm{O}_{2}$ avoids telomere erosion.

Moreover, hypoxia upregulated the expression of OCT4 and CXCR7 in MSCs, and deferred modifications in phenotypic characteristics such as morphology, cell size, and senescence. ${ }^{58}$ Furthermore, besides these effects, hypoxia also increased the levels of MSC-secreted factors, such as matrix metalloprotease-(1 and 3) and secreted lysyl oxidase $(\mathrm{LOX})$, which are required for migration and cell matrix adhesion. ${ }^{59}$

However, other authors described different results. For example, Pezzi et al. ${ }^{60}$ found that cells exposed to protracted hypoxia behaved similar to their controls in normoxia concerning viability, immunophenotyping, differentiation, and ROS levels. Cells subjected to low oxygen tensions $(4 \%-1 \%)$ showed lower proliferation, smaller cell size, greater cellular complexity, lower mitochondrial activity, and autophagy. These data validate a study by Holzwarth et al., ${ }^{61}$ that, by culturing MSCs in conditions of $21 \%, 5 \%$, $3 \%$, and $1 \%$ oxygen, concluded that hypoxia limits MSC's proliferation in incubation period of 7 days. This inconsistency could be due to heterogeneity of culture conditions, such as supplementation and period of exposure to hypoxia, as well as intradonor variability that may explain the contradictory effects of hypoxia on the proliferation and differentiation capacities of MSCs. ${ }^{61-64}$ Furthermore, donor's age directly worsens cell proliferative capacity, concurring to the variability of results. ${ }^{65}$

Supplementation with molecule affecting ROS levels has been tested in many studies. For example, El Alami et al. ${ }^{66}$ demonstrated that for human dental pulp stem cells (hDPSCs) cultured under $21 \% \mathrm{O}_{2}$, oxidative stress promotes the sequential activation of p38 MAPK, p21, and the nuclear factor erythroid 2-related factor 2 (Nrf-2) antioxidant defense pathway. The antioxidant properties of p21 depend on Nfr2 activity that upregulates HO-1 and NQO1. Therefore, incubation with Trolox, a water-soluble analog of vitamin $\mathrm{E}$, or with a p38 inhibitor, reestablishes high proliferation rate of hDPSCs even under $21 \% \mathrm{O}_{2}$.

\section{Source of ROS and Antioxidant Defense System in Stem Cells}

ROS include nonradical species, such as hydrogen peroxide and singlet oxygen, as well as radical species (superoxide, hydroxyl, hydroperoxy, peroxy, and alkoxy radicals). Biologically, superoxide and hydrogen peroxide play a pivotal role in modulating redox signaling. ${ }^{67}$ The effects exerted by these molecules is related to their nature, intracellular levels, and localization: ROS can be involved not only in macromolecule's oxidative damage and cell death induction, but also in signal transduction linked to cell proliferation and gene transcription activation. ${ }^{68}$ In particular, numerous experimental evidences suggest a clear 
correlation between intracellular $\mathrm{H}_{2} \mathrm{O}_{2}$ levels and features of stem and progenitor cells. ${ }^{10,41,69-71}$ As is well known, excess ROS contributes to pathological conditions, nevertheless, a proper and controlled ROS production is mandatory for physiological cellular functions, the so-called and previously cited "redox window" hypothesis. ${ }^{72,73}$

Much remains to be learned about the identification of the main ROS source in stem cells. In mammalian cells, a number of ROS sources are known, including: mitochondrial OXPHOS, ${ }^{67,74}$ plasma membrane NOXs,${ }^{75}$ cytochrome P450 , and b5 enzymes at endoplasmic reticulum level, ${ }^{76}$ peroxisome oxidases, ${ }^{77}$ lipoxygenases, ${ }^{78}$ and xanthine oxidase. ${ }^{79}$

The fewer mitochondria content of stem cell compared with their progeny is in accordance with their utilization of glycolysis rather than OXPHOS for ATP production. ${ }^{39,80}$ Since it is often assumed that mitochondria are the main ROS source, ${ }^{67}$ members of NOX family could represent major cellular sources of ROS in HSCs, as also suggested by Drehmer et al. ${ }^{81}$ in relation to the metabolic switches for adipogenic stem cell differentiation. hHSCs indeed express NOX1, 2, and 4 and various regulatory subunits of NOXs ${ }^{80,82}$ and Piccoli et al. estimated that NOX-mediated extramitochondrial $\mathrm{O}_{2}$ consumption accounts for about half of the endogenous cell respiration in hHSCs ${ }^{80}$ Interestingly, mouse BHSC-enriched LSK-cells express NOX1, 2, and 4, whereas NOX4 is not present in HPCs, $\mathrm{Lin}^{-}$cells, and mononuclear cells from mouse BM, suggesting that NOX4 expression is downregulated during HSC differentiation and that NOX4 may play an important role in the regulation of HSC function. ${ }^{83}$ However, the increase in ROS production in HSCs is associated with upregulation of NOX4 expression, ${ }^{83}$ but is not related to mitochondrial dysfunction nor elevated mitochondrial superoxide production. ${ }^{84}$

Nevertheless, it has been shown that cells, including HSCs, from $\mathrm{Bmil}^{-1-}$ mice exhibit abnormal mitochondrial function with consequently an increased ROS production. ${ }^{85}$ In addition, an elevation of mitochondrial biogenesis and oxidative activities seems to be related to an increased production of ROS in HSCs from Tsc1 ${ }^{-1-}$ mice. ${ }^{86}$

ROS derived from various cellular sources and compartments could be used by different stem cells to perform unique functions. For example, Udx1 (a dual NOX), allows the conversion of $\mathrm{O}_{2}{ }^{-}$to $\mathrm{H}_{2} \mathrm{O}_{2}$ to prevent polyspermy and regulate cleavage in the zygote of the sea urchin. ${ }^{87}$ Cardiovascular differentiation of ESCs depends on increased ROS generation derived from various NOXs. ${ }^{88}$ However, an increase in mitochondrial mass and production of ATP and ROS is linked to human ESC (hESC) differentiation. ${ }^{89}$

To regulate redox signaling and to counteract excessive amounts of ROS derived from aerobic metabolism, a complex antioxidant system plays an important role. In particular, MnSOD plays a primary role in the cell protection from mitochondrial ROS. Nevertheless, although MnSOD has been extensively studied in relation to aging and tumor biology, the crucial role of MnSOD in stem cell physiology still remains unclear. ${ }^{90}$ The cytosolic $\mathrm{Cu} / \mathrm{Zn}$ SOD isoform not only is present in stem cell but also represent a factor secreted by MSCs. Importantly, MSCs have been reported to restore the radiation-induced reduction of $\mathrm{Cu} / \mathrm{Zn}$ SOD levels after whole thorax irradiation, suggesting a paracrine action exerted by MSC-derived SOD1 in the protective function exerted by MSC. ${ }^{91}$
Outside mitochondria, the glutathione-based systems (GSH/GSSG ratio regulated by glutathione S-transferase, glutathione peroxidase/reductase) usually represent the major redox-regulatory mechanisms leading to $\mathrm{H}_{2} \mathrm{O}_{2}$-scavenging mechanism involving its reduction to water and a similar reaction is catalyzed by CAT inside the peroxisome.

Thioredoxin is mainly localized in the endoplasmic reticulum and reduces disulfide bonds of oxidatively modified proteins. Sundaramoorthy et al. ${ }^{92}$ demonstrated that the treatment with TXN, 24 hours following irradiation, mitigates radiation-induced cell injury of hematopoietic stem in mice.

\section{Natural Compounds to Optimize Expansion of Stem Cells In Vitro}

Many studies have explored the effect of natural antioxidant compounds against hyperoxia-induced oxidative stress in ex vivo cultures of different stem cells to increase cell proliferation, maintain potency, counteract senescence and DNA damages (Table 1). In particular, purified phytochemicals and their potential in vivo metabolites, plant extracts, combinations of purified compounds, and/or extracts have been investigated.

\section{Purified Phytochemicals}

Many purified phytochemicals have been studied for their ability to enhance proliferation and maintain stem cell potency, and the majority of them are polyphenolic compounds, in particular flavonoids (Fig. 1)

Epigallocatechin gallate [(-)-cis-3,3', $4^{\prime}, 5,5^{\prime}, 7$-hexahydr oxyflavane-3-gallate] is the most abundant and biologically active catechin in green tea. This compound is a polyphenol belonging to the flavonoid family whose members are known for their in vitro and in vivo antioxidant activity. ${ }^{93}$ Wang et al. ${ }^{94}$ showed that epigallocatechin gallate treatment $(10-40 \mu \mathrm{M})$ significantly increased cell proliferation of adult hippocampal neural progenitor cell cultures. Another study demonstrated that low concentrations $(0.1 \mu \mathrm{M})$ of epigallocatechin gallate increased the number of dividing cells and stimulated neurosphere formation of cochlea NSCs, confirming the positive effect of this flavonoid on stem cell proliferation. ${ }^{95}$

Quercetin $\left(3,3^{\prime}, 4^{\prime}, 5,7\right.$-pentahydroxyflavone) is a natural flavonoid present in many edible plants, including grapes, apples, onions, and berries. ${ }^{96}$ The effect of this flavonoid, along with its major in vivo metabolite, quercetin-3-Oglucuronide, has been considered in cultures of human embryonic NSCs. ${ }^{97}$ The results showed that quercetin and quercetin-3-O-glucuronide have totally opposed effects on cell viability. Quercetin $(20-60 \mu \mathrm{M})$ decreased NSC viability, decreased Akt phosphorylation, and increased apoptosis. In contrast, quercetin-3-O-glucuronide $(20-60 \mu \mathrm{M})$ increased proliferation through the Akt/cyclin D1 and BDNF signaling pathway. Quercetin's negative effect on cell viability was also observed in hESCs. In particular, quercetin $(25-200 \mu \mathrm{M})$ induced mitochondrial ROS production that were responsible for quercetin-mediated hESC cell death. ${ }^{98}$ From our point of view, as quercetin is a very active compound, the range of concentrations tested in these studies are too high to evoke a proliferative effect. Further studies should be carried out to assess lower quercetin 
Table 1. Phytochemicals with a Positive Effect on Stem Cell Proliferation and Stemness Maintenance In Vitro

\begin{tabular}{|c|c|c|c|c|}
\hline Compounds & Effective concentration & Type of stem cell & Molecular targets & References \\
\hline \multirow[t]{2}{*}{ Epigallocatechin-3-gallate } & $10-40 \mu \mathrm{M}$ & $\begin{array}{l}\text { Mice hippocampal } \\
\text { neuronal progenitor } \\
\text { cells }\end{array}$ & Not investigated & 88 \\
\hline & $0.1 \mu \mathrm{M}$ & Mouse cochlear NSCs & Not investigated & 89 \\
\hline Quercetin-3-O-glucuronide & $20-60 \mu \mathrm{M}$ & Human embryonic NSCs & $\uparrow A k t / c y c l i n$ D1 and $\uparrow$ BDNF signaling pathway & 91 \\
\hline Kaempferol & $20 \mu \mathrm{M}$ & mESCs & $\uparrow$ Nanog & 94 \\
\hline \multirow{2}{*}{ Naringenin } & $1-100 \mu \mathrm{g} / \mathrm{mL}$ & hBMSCs & Not investigated & 96 \\
\hline & $1-100 \mu \mathrm{g} / \mathrm{mL}$ & hAFSCs & Not investigated & 97 \\
\hline \multirow[t]{6}{*}{ Icariin } & $10 \mathrm{nM}-1 \mu \mathrm{M}$ & hBMSCs & & 99 \\
\hline & $100 \mathrm{nM}$ & mNSCs & $\uparrow E R K$ & 100 \\
\hline & $10 \mu \mathrm{M}$ & hNSCs & $\uparrow$ FGFR $1, \uparrow$ Wnt family, $\downarrow$ GSK $-3 \beta$ & 101 \\
\hline & $100 \mu \mathrm{M}$ & rNSCs & $\uparrow$ cyclin D $1, \uparrow \mathrm{p} 21$ & 102 \\
\hline & $20-320 \mu \mathrm{M}$ & rBMSCs & $\uparrow \mathrm{pERK}, \uparrow \mathrm{pp} 38, \uparrow$ Elk-1, $\uparrow \mathrm{c}-\mathrm{Myc}$ & 103 \\
\hline & $100 \mathrm{nM}$ & rASCs & $\uparrow$ RhoA/ROCK signaling pathway & 104 \\
\hline \multirow[t]{2}{*}{ Icaritin } & $5-10 \mathrm{nM}$ & mESCs & $\begin{array}{l}\downarrow \text { CDX2 and p130, } \uparrow \text { cyclin E/CDK2, } \uparrow \text { Oct } 4, \uparrow \text { Nanog, } \\
\uparrow \text { Klf4, } \uparrow \text { Sox2 }\end{array}$ & 99,106 \\
\hline & $100 \mathrm{nM}$ & hMSCs & $\uparrow$ STAT3 signaling pathway & 107 \\
\hline \multirow{2}{*}{ Chrysin } & Loaded on 3D nanofibers ( $15 \% \mathrm{wt}$ ) & hASCs & $\uparrow$ Oct $4, \uparrow$ Nanog, $\uparrow$ Rex $-1, \uparrow$ Sox 2 & 108 \\
\hline & Loaded on 3D nanofibers $(5 \mu \mathrm{M})$ & mMSCs & $\downarrow$ cyclin $\mathrm{C} 1, \uparrow$ cyclin B $1, \uparrow$ cyclin E1 & 109 \\
\hline $3,2^{\prime}$-dihydroxyflavone & $5 \mu \mathrm{M}$ & mESCs and iPSCs & $\begin{array}{l}\uparrow \mathrm{STA} 3, \uparrow \text { Akt, } \downarrow \text { GSK }-3 \beta, \downarrow \text { ERK, } \uparrow \text { Oct } 4, \uparrow \text { Nanog, } \uparrow \text { Fgf } 4 \text {, } \\
\uparrow \text { Sox } 2, \uparrow \text { Cripto }\end{array}$ & 110 \\
\hline Morin hydrate & $1-2 \mathrm{mg} / \mathrm{L}$ & mNSCs & & 112 \\
\hline \multirow[t]{5}{*}{ Resveratrol } & $10 \mathrm{nM}-10 \mu \mathrm{M}$ & hMSCS & $\uparrow \mathrm{NO} / \mathrm{cGMP}$ signal & 114 \\
\hline & $10 \mathrm{nM}-10 \mu \mathrm{M}$ & hMSCs & $\uparrow$ Estrogen receptor dependent MAPK pathway & 115 \\
\hline & $0.1 \mu \mathrm{M}$ & hMSCs & $\uparrow$ Sirtuin $1, \uparrow$ Sirtuin $2, \uparrow$ Birc4, $\uparrow$ Birc5 & 116 \\
\hline & $50-500 \mathrm{nM}$ & mESCs & $\uparrow$ Pcna, $\uparrow$ cyclin D $\uparrow$ cyclin $A, \uparrow$ Oct $4, \uparrow$ Sox 2 , & 117 \\
\hline & $50 \mu \mathrm{M}$ & hESCs & $\uparrow$ SIRT1-ERK signaling pathway & 118 \\
\hline Di-(2-ethylhexyl) phthalate & $100-600 \mu \mathrm{M}$ & rNSCs & $\uparrow$ Sox2 & 132 \\
\hline Silymarin & $50-100 \mu \mathrm{gM}$ & hBMSCs & $\uparrow \mathrm{GSH}$ & 139 \\
\hline Daucosterol & $5 \mu \mathrm{M}$ & rNSCs & $\uparrow$ IGF1, ^pAkt & 119 \\
\hline Salvianolic acid B & $5-20 \mu \mathrm{M}$ & rNSPCs & $\uparrow \mathrm{pAkt}, \uparrow$ Nestin, $\uparrow$ Notch-1 & 121 \\
\hline Oleuropein & $10-100 \mu \mathrm{M}$ & hASCs & 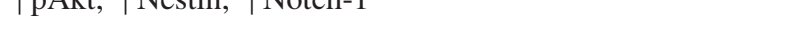 & 123 \\
\hline Curcumin & $0.1-0.5 \mu \mathrm{M}$ & C17.2 cells & $\uparrow \mathrm{pERK}, \uparrow \mathrm{pp} 38$ & 125 \\
\hline Astaxanthin & $5-10 \mathrm{ng} / \mathrm{mL}$ & $\begin{array}{l}\text { Mouse neuronal progenitor } \\
\text { cells }\end{array}$ & $\begin{array}{l}\uparrow \mathrm{PI} 3 \mathrm{~K} \text { and MEK signaling pathway, } \uparrow \text { Rex } 1, \uparrow \mathrm{CDK} 1, \\
\uparrow \mathrm{CDK} 2, \uparrow \text { Oct } 4, \uparrow \text { Sox } 2, \uparrow \text { Nanog, } \uparrow \text { Klf4 }\end{array}$ & 128 \\
\hline Essential oil of Lippia origanoides & $1 \mu \mathrm{g} / \mathrm{mL}$ & hASCs & & 130 \\
\hline $\begin{array}{l}\text { Hydroethanolic extract Cirsium } \\
\text { vulgare }\end{array}$ & $200-1000 \mu \mathrm{g} / \mathrm{mL}$ & rNSCs & & 132 \\
\hline Water extract of Hibiscus sabdariffa & $0.5-1.0 \mu \mathrm{g} / \mathrm{mL}$ & mBMSCs & $\uparrow \mathrm{GSH}, \uparrow \mathrm{SOD}$ & 135 \\
\hline Drynaria fortune & $0.1 \mathrm{~g} / \mathrm{L}$ & DPSCs & & 136 \\
\hline Epimedium & $200-400 \mu \mathrm{g} / \mathrm{mL}$ & Rat hippocampal NSCs & & 137 \\
\hline $\begin{array}{l}\text { Blueberry extract, green tea extract, } \\
\text { carnosine, vitamin D3 }\end{array}$ & $500 \mathrm{ng} / \mathrm{mL}, 500 \mathrm{ng} / \mathrm{mL}, 20 \mu \mathrm{M}, 5 \mu \mathrm{M}$ & $\begin{array}{l}\text { Human hematopoietic } \\
\text { stem cells }\end{array}$ & & 140 \\
\hline $\begin{array}{l}\text { Epigallocatechin-3-gallate, } \\
\text { sulforaphane }\end{array}$ & $10 \mu \mathrm{M}, 1 \mu \mathrm{M}$ & hAFSCs & $\uparrow \mathrm{GSH}, \uparrow \mathrm{NQO} 1, \uparrow \mathrm{TR}, \uparrow$ Oct $4, \uparrow$ Nanog, $\downarrow \mathrm{p} 16, \downarrow \beta$-gal & 141 \\
\hline
\end{tabular}

3D, three-dimensional; ASCs, adipose-derived stem cells; ERK, extracellular signal-regulated kinase; hAFSCs, human amniotic fluid-derived stem cells; hBMSCs, human bone mesenchymal stem cells; hESCs, human embryonic stem cells; iPSCs, induced pluripotent stem cells; mBMSC; mESCs, murine embryonic stem cells; mMSCs, mouse mesenchymal stem cells; NSCs, neural stem cells; ROCK, rho-associated protein kinase; STAT3, signal transduction activator transcription factor 3; rASCs; rBMSCs; rNSCs; rNSPCs; mNSCs; hNSCs; hASCs; TR, thioredoxin reductase. 


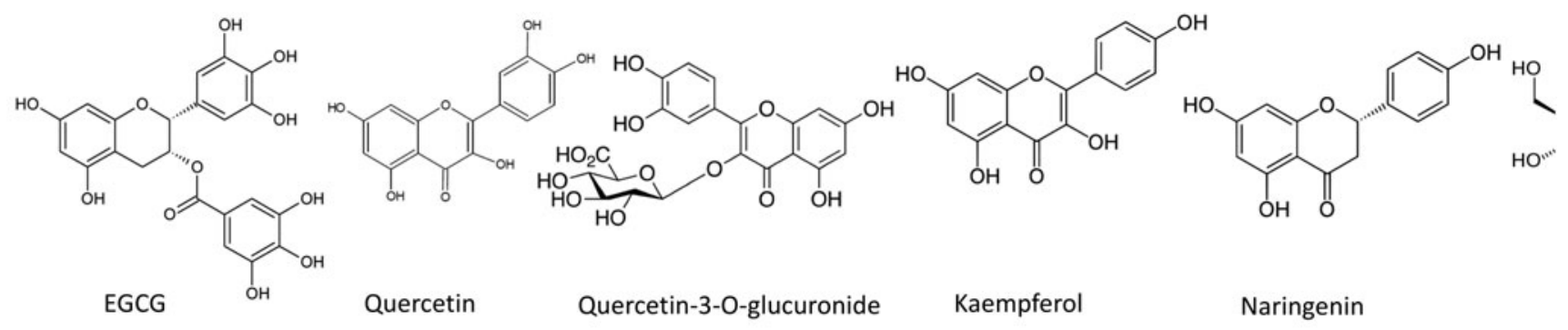<smiles>O=c1c(O)c(-c2ccccc2O)oc2ccccc12</smiles>

Chrysin<smiles>O=c1c(O)c(-c2ccc(O)cc2O)oc2cc(O)cc(O)c12</smiles>

Morin<smiles>Oc1ccc(/C=C/c2cc(O)cc(O)c2)cc1</smiles>

Resveratrol<smiles>COc1cccc(/C=C/C(=O)CC(=O)/C=C/c2ccc(O)c(OC)c2)c1</smiles>

Curcumin<smiles>C=CC=CCC(OC(=O)C=CC)C(=O)OC(=O)C(Cc1ccc(O)c(O)c1)OC(=O)O</smiles><smiles>CC1=C(/C=C/C=C(C)/C=C/C=C/C=C(C)/C=C/C=C(C)/C=C/C(C)=C/C=C/C(C)(C)C)C(C)(C)CC(O)C1=O</smiles>

FIG. 1. Chemical structure of phytochemicals used to optimize expansion of stem cell in vitro.

concentrations on NSCs viability. Our hypothesis is reinforced by the study of Nichols et al., ${ }^{99}$ which showed that $0.3-3 \mu \mathrm{M}$ quercetin, but not $10 \mu \mathrm{M}$ quercetin, increased cell viability of primary cortical neuron subjected to oxygenglucose deprivation.

Kaempferol (3,4',5,7-tetrahydroxyflavone) is a flavonoid structurally similar to quercetin apart from the lack of the hydroxyl group in $3^{\prime}$ position. The treatment with high concentrations $(200 \mu \mathrm{M})$ of kaempferol negatively affected murine ESCs (mESCs) viability and growth and increased mitochondrial ROS, although the resulting cell colonies were smaller but remain pluripotent. ${ }^{100}$ Nevertheless, lower concentrations $(20 \mu \mathrm{M})$ of this flavonoid increased the pluripotency marker expression in mESCs but, at the same time, inhibited proper differentiation of mESCs.

Naringenin (4',5,7-trihydroxyflavanone) is a flavonoid compound belonging to the flavanone class mostly present in citrus fruits, including lemon, orange, tangerine, and grapefruit. ${ }^{101}$ The supplementation of naringenin $(1-100 \mu \mathrm{g} / \mathrm{mL})$ to human bone MSCs (hBMSCs) resulted in enhanced cell proliferation. ${ }^{102}$ The activity of naringenin was also studied in human amniotic fluid-derived stem cells (hAFSCs) by Liu et al. ${ }^{103}$ In agreement with the previous study, in the presence of naringin, hAFSC proliferation increased dose dependently between 1 and $100 \mu \mathrm{g} / \mathrm{mL}$. Unfortunately, no mechanisms have been suggested to explain the observed effect on cell proliferation.

Icariin (4'-O-methyl-8- $\gamma, \gamma$-dimethylallylkaempferol-3rhamnoside-7-glucoside) and its derivatives are flavonoids obtained from traditional Chinese medicinal herbs of the Epimedium genus. ${ }^{104}$ The first study that observed a promoting activity of icariin on proliferation of stem cells was carried out by Fan et al. ${ }^{105}$ Icariin in the range $10 \mathrm{nM}-1 \mu \mathrm{M}$ induced the in vitro cell proliferation of hBMSCs. The same effect was observed on NSCs derived from forebrains of mice embryos. ${ }^{106}$ Icariin promoted neurosphere formation and proliferation of NSCs in a dose-dependent manner, achieving the maximum effects at $100 \mathrm{nM}$. The authors suggested that these effects were partially mediated by the extracellular signal-regulated kinase (ERK)/MAPK. The regulatory roles of icariin in increasing cell proliferation of NSCs in vitro was also investigated in human NSCs derived from fetuses. ${ }^{107}$ The treatment of human NSCs with $10 \mu \mathrm{M}$ icariin led to a higher proliferation rate compared with control cells. The microarray analysis carried out in this study showed that icariin modulates the expression of different genes in the Wnt and bFGF pathways, in particular, icariin significantly enhanced the expression of FGFR1 and three important Wnt family members: CTNNB1, FZD7, DVL3, and, at the same time, reduced the expression of GSK-3 $\beta$. These results were further defined and broadened by $\mathrm{Fu}$ et al. ${ }^{108}$ who observed that icariin promoted the growth and proliferation of rat hippocampus NSCs in a dose-dependent manner through the regulation of the cell cycle genes, cyclin D1 and p21. Higher concentrations of icariin $(20-320 \mu \mathrm{M})$ increased proliferation of rat BMSCs. ${ }^{109}$ The increased rBMSC proliferation appeared to be mediated by the phosphorylation of ERK and p38 and by the overexpression of MAPK targets, Elk-1 and c-Myc. Another study evidenced that $100 \mathrm{nM}$ icariin promotes in vitro proliferation of rat adipose-derived stem cells (ASCs) through the RhoA and Rho-associated protein kinase (ROCK) signaling pathways. ${ }^{110}$ Icariin has also been investigated in relation to the cellular damages caused by oxidative stress experienced during cryopreservation and thawing. ${ }^{111}$ The addition of icariin to the freezing solution containing DMSO significantly increased the postthawed cell viability, decreased the apoptosis rate, improved cell adherence, and maintained the mitochondrial functions, as compared with the freezing solution containing DMSO alone. Moreover, icariin inhibited oxidative stress and upregulated heat shock proteins 70 and 90 . 
Icaritin [3,5,7-trihydroxy-2-(4-methoxyphenyl)-8-(3-methyl but-2-enyl)chromen-4-one], an icariin derivative, has been shown to increase proliferation and enhance self-renewal of mouse ESCs. ${ }^{105,112}$ Icaritin cooperates and stimulates ER $\alpha$, functioning as a effective inhibitor of CDX2 and p130, which successively activates cyclin E/CDK2 signaling to trigger G1/S phase progression and upregulates pluripotency markers like Klf4, Oct4, Nanog, and Sox2. The proliferative effect of different concentrations of icaritin for different times has also been investigated in MSCs. ${ }^{113}$ Icaritin treatment increased MSC proliferation after 2 and 3 weeks of exposure with the highest MSC proliferation measured with $100 \mathrm{nM}$ icaritin treatment. The study suggests that icaritin promotes the proliferation of human adult MSCs by the activation of the signal transduction activator transcription factor 3 (STAT-3), with a resulting increase of cysteine (C)$\mathrm{X}-\mathrm{C}$ motif chemokine receptor 4 (CXCR4) expression and activity.

Another highly investigated flavonoid in relation to the optimization of stem cell cultures in vitro is chrysin (5,7dihydroxyflavone), a flavone predominantly present in honey, propolis, and passion fruit. ${ }^{114}$ In a recent article, ASCs were cultured on three-dimensional nanofibrous mats loaded with ASCs. ${ }^{114}$ Interestingly, ASCs, cultured in the presence of chrysin, exhibited improved adhesion and increased viability compared with cultures on nanofibers without chrysin or tissue culture polystyrene. Moreover, ASCs on chrysin-based nanofibers showed enhanced stemness maintenance capability evidenced by the overexpression of four stemness markers: Nanog, Sox-2, Oct-4, and Rex-1. In another study, chrysin was incorporated into biocomposite scaffolds encompassing chitosan, carboxymethyl cellulose, and nanohydroxyapatite, and mouse MSCs (mMSCs) were seeded on these scaffolds. ${ }^{115}$ Chrysin released from scaffolds enhanced cell proliferation downregulating cyclin $\mathrm{C} 1 \mathrm{mRNA}$, thus inducing the transition of cells from G0 phase to G1 phase, upregulating Cyclin B1 and $\mathrm{E} 1$ and promoting the progression of mMSCs from G1 phase to $S$ and $G 2 / M$ phases.

A study explored the effect of different flavonoids characterized by different hydroxylation pattern in the $\mathrm{B}$ ring of skeleton of diphenylpropane (C6 C3 C6) on cell growth and pluripotency marker expression in mouse embryonic stem cells and iPSCs. ${ }^{116}$ Among the tested compounds only 3,2'dihydroxyflavone increased cell growth and the expression of pluripotency marker Sox2, Oct4, Nanog, Cripto, and Fgf4. The mechanisms behind these effects were a strong activation (AKT and STAT3) or inhibition (ERK and GSK3 $\beta$ ) of self-renewal-related kinase of both ESCs and iPSCs. These data suggest that $3,2^{\prime}$-dihydroxyflavone could be useful for the maintenance of high-quality pluripotent ESCs and iPSCs.

Morin hydrate $\left(3,5,7,2^{\prime}, 4^{\prime}\right.$ pentahydroxyflavone) is a polyphenol compound extracted from Prunus dulcis, Castanea sativa, Morus alba, and other fruits. ${ }^{117}$ It has been observed that morin hydrate $(1-2 \mathrm{mg} / \mathrm{L})$ promotes growth and proliferation of isolated mouse inner ear NSCs as measure by MTT assay and BrdU incorporation. ${ }^{118}$

Resveratrol (3, 5, 4'-trihydroxystilbene), a nonflavonoid polyphenol with stilbene structure, is found in different plants such as cranberries, blueberries, grapes, peanuts, and eucalyptus. ${ }^{119}$
The first studies that evidenced a stimulatory activity of resveratrol on stem cell proliferation were conducted on human bone marrow-derived mesenchymal stem cells (hMSCs). ${ }^{120,121}$ In particular, $10 \mathrm{nM}$ to $10 \mu \mathrm{M}$ resveratrol induced mBMSCs cell proliferation measured by $\left[{ }^{3} \mathrm{H}\right]-$ thymidine incorporation through the NO/cGMP signal ${ }^{120}$ and stimulates hBMSCs proliferation through an estrogen receptor-dependent mechanism and coupling to ERK1/2 phosphorylation. ${ }^{121}$ To gain better understanding of the effect of this polyphenols on MSCs, Peltz et al. ${ }^{122}$ investigated the effect of short-term (14 days) versus long-term (28-70 days) exposure to resveratrol at different concentrations $(0.1-10 \mu \mathrm{M})$ in hMSCs. Resveratrol showed a dosedependent activity on hMSCs self-renewal as a result of its combinatorial effect on cell doubling time, and on cell senescence and cell proliferation rate. At $0.1 \mu \mathrm{M}$, resveratrol showed the highest benefit, enhancing stem cell self-renewal over both short- and long-term exposure, meanwhile 5 or $10 \mu \mathrm{M}$ treatment inhibited cell self-renewal. In accordance with these observations, the expression of genes involved in cell survival (Sirtuin 1, Sirtuin 2, Birc4, and Birc5) was increased by a lower resveratrol concentration but inhibited by a higher resveratrol concentration. A study conducted on mouse ESCs showed that $\mathrm{nM}$ concentrations of resveratrol (50 and $500 \mathrm{nM}$ ) restored the pluripotency of ESCs differentiated with retinoic acid by modulating the JAK-STAT3 signaling pathway which, in turn, stimulates the transcription of the stemness key factors, OCT4 and SOX2. ${ }^{123}$ In addition, the same resveratrol concentrations enhanced ESC proliferation through the induction of genes related to proliferation, such as Cyclin A, Cyclin D, and Pcna. Of note, the authors observed that higher concentrations of resveratrol played a nonsignificant role in the regulation of ESC self-renewal suggesting that the timing and concentration of resveratrol are fundamental in eliciting its final activity on self-renewal of ESCs. These aspects were further investigated by Safaeinejad et al. ${ }^{124}$ who indicated that $50 \mu \mathrm{M}$ resveratrol might induce cell proliferation of hESCs by the modulation of the cell cycle. Interestingly, this resveratrol concentration did not negatively affect pluripotent markers and upregulated antiapoptotic markers. The authors suggested that resveratrol maintained self-renewal of hESCs at least in part through "SIRT1-MEK/ERK" axis.

Daucosterol ( $\beta$-sitosterol $\beta$-D-glucoside) is a phytosterol present in many higher plants, especially in plant oils, nuts, and seeds. ${ }^{125}$ It has been observed that $5 \mu \mathrm{M}$ daucosterol induced rat NSC proliferation and increased the percentage of daughter cells reentering the cell cycle by the modulation of numerous genes, especially increasing the expression of IGF1 and phosphorylation of Akt. ${ }^{125}$

Salvianolic acid B is a hydrophilic compound present in Salvia miltiorrhiza Bunge, commonly known as Danshen and widely used for the treatment of various diseases, such as cardiovascular disease, Alzheimer's, hyperlipidemia, and acute cerebrovascular disease. ${ }^{126}$ Salvianolic acid B significantly increased the proliferation of rat neural stem/precursor cells (NSPCs) by activating the PI3K/Akt signal pathway and maintained NSPC's self-renewal by increasing the expression of two self-renewal markers, Nestin and Notch-1. ${ }^{127}$

Oleuropein is a phenolic compound present in olive oil with high antioxidant capacity. ${ }^{128}$ Human adipose-derived 
MSCs showed a higher proliferative rate in the presence of $10-100 \mu \mathrm{M}$ oleuropein as measured by WST assay. ${ }^{129}$

Curcumin is a polyphenol isolated from the rhizomes of the plant Curcuma longa (turmeric) and is a commonly used spice throughout the world. ${ }^{130}$ This natural antioxidant has been investigated in relation to the proliferation of multipotent neural progenitor cells (C17.2 cells). ${ }^{131}$ Low doses (0.1 and $0.5 \mu \mathrm{M}$ ) of curcumin induced $\mathrm{C} 17.2$ cell proliferation, whereas high doses $(\geq 10 \mu \mathrm{M})$ triggered a cytotoxic effect. The authors demonstrated that the mechanisms by which curcumin elicits this effect is by activating ERK and p38 MAP kinases.

Astaxanthin is a xanthophyll carotenoid ubiquitous in nature, especially in the marine environment, and is found in high amounts in algae, and in aquatic animals such as salmon, trout, krill, and lobster. ${ }^{132}$ It has been shown that astaxanthin possesses a particularly strong antioxidant capacity compared with other carotenoids. ${ }^{133}$ Treatment with astaxanthin (5$10 \mathrm{ng} / \mathrm{mL}$ ) increased proliferation and colony formation of mouse neural progenitor cells in a dose/time-dependent manner through the activation of the PI3K and MEK signaling pathways. ${ }^{134}$ Moreover, astaxanthin upregulated transcription factors associated to proliferation, such as CDK1, CDK2, and Rex1, and increased the expression of stemness genes (OCT4, Nanog, SOX2, and KLF4) suggesting that astaxanthin can also improve stem cell potency.

In conclusion, different phytochemicals showed a promising activity in increasing stem cell proliferation and promoting stemness maintenance suggesting their use in ex vivo expansion of stem cells

\section{Plant Extracts}

Not only purified phytochemicals, but also extracts from officinal and not officinal plants have been demonstrated to influence stem cell expansion and stemness maintenance.

Lippia origanoides is an aromatic plant widely found throughout the Brazilian Amazon. Its essential oil has antioxidant activity, thanks to the presence of the monoterpenoids, thymol, p-cymene, and myrcene, and the sesquiterpene, caryophyllene. ${ }^{135}$ The supplementation of the essential oil from $L$. origanoides $(1 \mu \mathrm{g} / \mathrm{mL})$ in the culture medium of stem cells isolated from human adipose tissue induced a strong increase of cell proliferation especially at passage $3 .{ }^{136}$ The authors suggested that this effect could be attributed to thymol, the principal constituent of the oil of $L$. origanoides used in the study $(88.2 \%)$.

Cirsium vulgare is a common plant belonging to Asteraceae family whose main components are flavonoids and phenolic acids. ${ }^{137}$ The effects of a $C$. vulgare hydroethanolic extract $(200-1000 \mu \mathrm{g} / \mathrm{mL})$ and its main component, di-(2ethylhexyl) phthalate $(100-600 \mu \mathrm{M})$ have been investigated on the proliferation and pluripotency of neonatal rat hippocampusderived NSCs. Both the extract and di-(2-ethylhexyl) phthalate at the higher concentrations were able to increase proliferation and the phthalate upregulated the expression of the stemness marker Sox $2 .^{138}$

Hibiscus sabdariffa is a plant rich in flavonoids whose biological effects seem to be mediated by its antioxidant activity. ${ }^{139,140}$ The supplementation of a water extract of $H$. sabdariffa to murine bone marrow-derived hematopoietic stem cells showed a cell-genoprotective potential and modulated proliferation and intracellular antioxidant status, without causing a remarkable loss of surface marker expression for HSC. ${ }^{141}$

Huang et al. ${ }^{142}$ studied the proliferative effect of a commercial flavonoid extract of Drynaria fortune, a common type of traditional Chinese herb, on stem cells isolated from rat dental pulp. The extract $(0.01-0.1 \mathrm{~g} / \mathrm{L})$ induced dental pulp stem cell proliferation in a dose-dependent manner by increasing the number of stem cells entering into $S$ phase dose dependently.

Epimedium flavonoids, extracted from a traditional Chinese Epimedium herb, promoted the proliferation of rat NSCs. ${ }^{143}$ Unfortunately, the authors did not characterize the extract they used.

Silymarin, a combination of flavonolignans obtained from Silybum marianum, has been shown to have a strong antioxidant activity. ${ }^{144}$ Silymarin $(50$ and $100 \mu \mathrm{M})$ increased cell viability of MSCs from human bone marrow by elevating intracellular GSH. ${ }^{145}$

\section{Combination of Purified Phytochemicals and/or Plant Extracts}

One of the first study that took into account the possibility to use a combination of natural antioxidant compounds to stimulate the proliferation of stem cells was conducted by Bickford et al. ${ }^{146}$ Human hematopoietic stem cells derived from bone marrow were supplemented with different concentrations of catechin, carnosine, blueberry extract, green tea extract, and vitamin $\mathrm{D}_{3}$ alone or in combination. All the tested compounds exhibited a positive effect on cell proliferation, although the combined treatments showed a stronger effect with respect to the single treatments. In particular, the combination of blueberry extract, green tea extract, carnosine, and vitamin $\mathrm{D}_{3}$ led to a higher proliferation rate with respect to the positive controls treated with human granulocyte colony-stimulating factor. Of all the tested compounds, blueberry extract significantly increased cell proliferation when combined with the other compounds.

Very recently, we demonstrated that a combination of epigallocatechin-3-gallate and sulforaphane exhibited a higher efficacy against oxidative stress induced by hyperoxia with respect to the single antioxidant treatments in hAFSCs. ${ }^{147}$ In particular, the combined treatment was more effective in reducing endogenous ROS generation, enhancing GSH levels and increasing the endogenous antioxidant enzymes glutathione reductase, $\mathrm{NAD}(\mathrm{P}) \mathrm{H}$ :quinone oxidoreductase-1 (NQO1), and thioredoxin reductase (TR). Moreover, the combined treatment upregulated the pluripotency markers, Oct4 and Nanog, and downregulated the senescence-associated gene markers, p16 and $\beta$-gal.

Luo et al. ${ }^{148}$ investigated the effect of two different combinations of antioxidants, a proprietary antioxidant supplement from Sigma-Aldrich (AOS, Catalogue Number: Sigma $\mathrm{A} 1345$ ) at 10,000-, 50,000-, and 200,000-fold dilution, and a homemade cocktail of L-ascorbate, L-glutathione $(20 \mathrm{mM})$, and $\alpha$-tocopherol acetate at the concentrations of 20,4 , and $1 \mu \mathrm{M}$, respectively, on genomic stability of iPSCs during long-term ex vivo expansion. Both the antioxidant treatment did not reduce cell growth and maintained stemness up to 2 months. Furthermore, the expression of 53BP1 and ATM, two critical molecules involved in DNA damage and repair, ${ }^{149,150}$ were not modulated by the antioxidant 


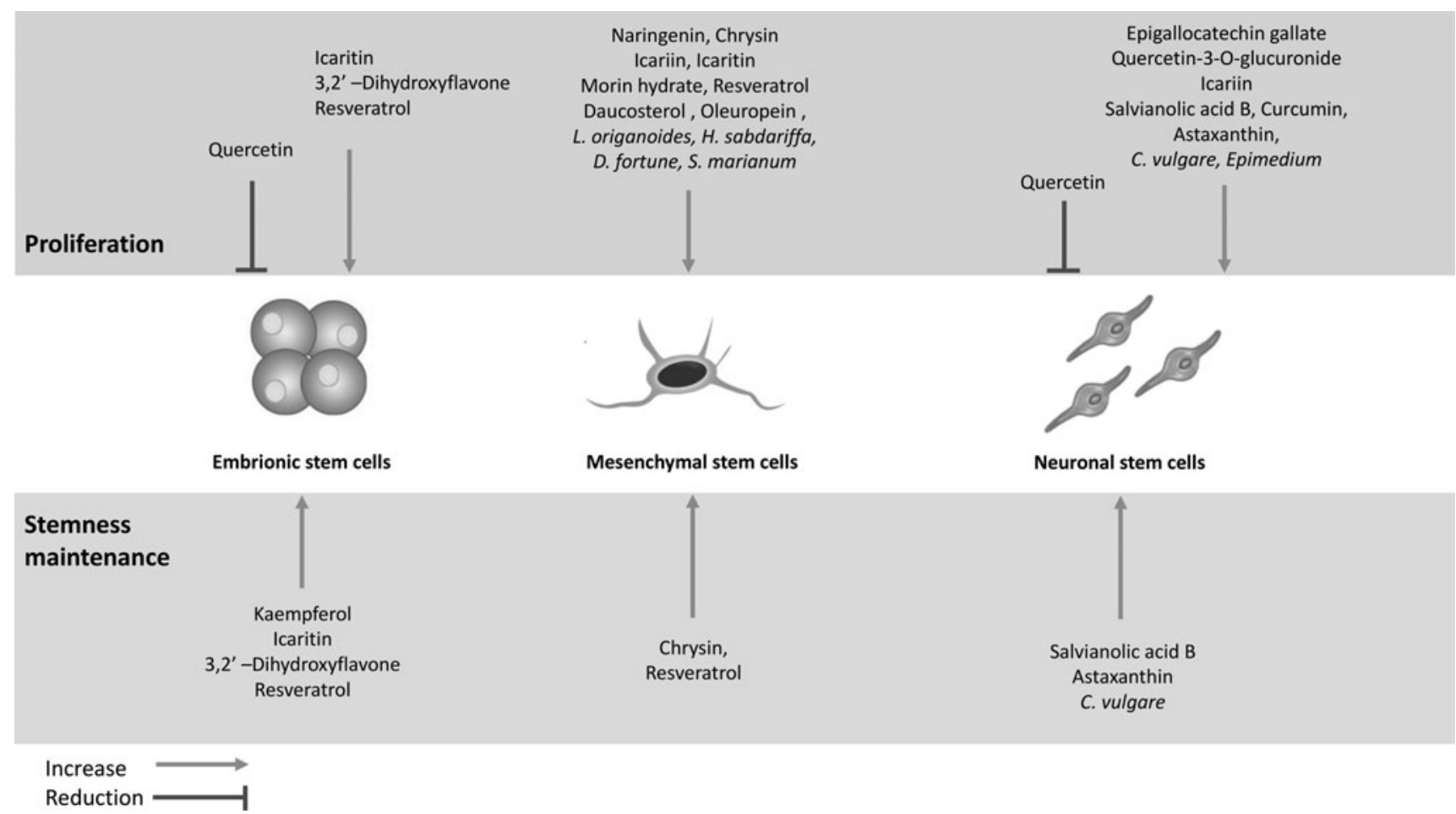

FIG. 2. Effect of phytochemicals and plant extracts on proliferation and stemness maintenance of different stem cell types.

supplementation, and array CGH analysis demonstrated a reduction of the genetic aberration events only in iPSC line supplemented with the homemade antioxidant cocktail. Of course, further experiments are needed to corroborate the benefit of antioxidants for long-term in vitro expansion of iPSCs.

In conclusion, the use of different phytochemicals or plant extracts demonstrated to be effective in reducing hyperoxiainduced damage in vitro. Of note, any compounds elicited its effect on cell proliferation or stemness maintenance targeting specific molecular targets and at different concentrations in the different cell cultures (Table 1). On these bases, the use of a combination of different phytochemicals and plant extracts seems to be the most promising approach to maximize the effect.

\section{Conclusions}

Today, the potential application of stem cells is dramatically increasing, and stem cell therapy will probably be applied in numerous chronic degenerative disease therapies in the future.

So, the maintenance of high-quality stem cells in culture without any side effect in proliferation, potency, or differentiation potential will be critical for all present and future biomedical applications. The best way to isolate, culture, and maintain stem cells from primary cultures should be under their physiological conditions, that is, low oxygen concentration and low glucose. Nevertheless, this often is not possible due to economical and/or practical reasons and therefore, the possibility to use natural antioxidants compounds represents a potentially very effective alternative. The use of natural products, and above all of natural phy- tochemicals, opens new frontiers. Many of these compounds, generally recognized as safe by the American Food and Drug Administration, can act at different molecular and cellular levels to modulate proliferation and stemness maintenance in several stem cell types (Fig. 2). Further studies are necessary to deepen the knowledge on the wide world of natural compounds that could be used in stem cell cultures, on their mechanisms of action, and on the optimal dose and association of different phytochemicals to give an important contribution to stem cell application in regenerative medicine.

\section{Acknowledgment}

Data reported in this review were partly obtained, thanks to the support of Fondazione Cassa di Risparmio di Bologna (Italy).

\section{Author Disclosure Statement}

No competing financial interests exist.

\section{Funding Information}

\section{References}

1. Siegel G, Schäfer R, Dazzi F. The immunosuppressive properties of mesenchymal stem cells. Transplantation 2009;87:S45-S49.

2. Chow DC, Wenning LA, Miller WM, Papoutsakis ET. Modeling $\mathrm{pO}(2)$ distributions in the bone marrow hematopoietic compartment. I. Krogh's model. Biophys J 2001; 81:675-684. 
3. Antoniou ES, Sund S, Homsi EN, Challenger LF, Rameshwar P. A theoretical simulation of hematopoietic stem cells during oxygen fluctuations: Prediction of bone marrow responses during hemorrhagic shock. Shock 2004; 22:415-422.

4. Rodrigues CA, Diogo MM, da Silva CL, Cabral JM. Hypoxia enhances proliferation of mouse embryonic stem cell-derived neural stem cells. Biotechnol Bioeng 2010; 106:260-270

5. Dos Santos F, Andrade PZ, Boura JS, Abecasis MM, da Silva CL, Cabral JM. Ex vivo expansion of human mesenchymal stem cells: A more effective cell proliferation kinetics and metabolism under hypoxia. J Cell Physiol 2010;223:27-35.

6. Hung SP, Ho JH, Shih YR, Lo T, Lee OK. Hypoxia promotes proliferation and osteogenic differentiation potentials of human mesenchymal stem cells. J Orthop Res 2012;30:260-266.

7. Lavrentieva A, Majore I, Kasper C, Hass R. Effects of hypoxic culture conditions on umbilical cord-derived human mesenchymal stem cells. Cell Commun Signal 2010; $8: 18$.

8. Efimenko A, Starostina E, Kalinina N, Stolzing A. Angiogenic properties of aged adipose derived mesenchymal stem cells after hypoxic conditioning. J Transl Med 2011; 9:10.

9. Kim JH, Song SY, Park SG, Song SU, Xia Y, Sung JH. Primary involvement of NADPH oxidase 4 in hypoxiainduced generation of reactive oxygen species in adiposederived stem cells. Stem Cells Dev 2012;21:2212-2221.

10. Urao N, Ushio-Fukai M. Redox regulation of stem/progenitor cells and bone marrow niche. Free Radic Biol Med 2013;54:26-39.

11. Estrada JC, Albo C, Benguría A, et al. Culture of human mesenchymal stem cells at low oxygen tension improves growth and genetic stability by activating glycolysis. Cell Death Differ 2012;19:743-755.

12. Fehrer C, Brunauer R, Laschober G, et al. Reduced oxygen tension attenuates differentiation capacity of human mesenchymal stem cells and prolongs their lifespan. Aging Cell 2007;6:745-757.

13. Mohamadnejad M, Pournasr B, Bagheri M, et al. Transplantation of allogeneic bone marrow mesenchymal stromal cell-derived hepatocyte-like cells in homozygous familial hypercholesterolemia. Cytotherapy 2010;12:566-568.

14. Casciaro F, Beretti F, Zavatti M, et al. Nuclear Nox4 interaction with prelamin $\mathrm{A}$ is associated with nuclear redox control of stem cell aging. Aging (Albany NY) 2018;10: 2911-2934.

15. Karimi-Busheri F, Rasouli-Nia A, Weinfeld M. Key issues related to cryopreservation and storage of stem cells and cancer stem cells: Protecting biological integrity. Adv Exp Med Biol 2016;951:1-12.

16. Angeloni C, Leoncini E, Malaguti M, Angelini S, Hrelia P, Hrelia S. Modulation of phase II enzymes by sulforaphane: Implications for its cardioprotective potential. J Agric Food Chem 2009;57:5615-5622.

17. Lu MC, Ji JA, Jiang ZY, You QD. The Keap1-Nrf2-ARE pathway as a potential preventive and therapeutic target: An update. Med Res Rev 2016;36:924-963.

18. Islam MS, Nagasaka R, Ohara K, et al. Biological abilities of rice bran-derived antioxidant phytochemicals for medical therapy. Curr Top Med Chem 2011;11:18471853.
19. Ma Y, Zeng M, Sun R, Hu M. Disposition of flavonoids impacts their efficacy and safety. Curr Drug Metab 2014; $15: 841-864$.

20. Minich DM, Bland JS. A review of the clinical efficacy and safety of cruciferous vegetable phytochemicals. Nutr Rev 2007;65:259-267.

21. Shipkowski KA, Betz JM, Birnbaum LS, et al. Naturally complex: Perspectives and challenges associated with Botanical Dietary Supplement Safety assessment. Food Chem Toxicol 2018;118:963-971.

22. Bertin E, Piccoli M, Franzin C, et al. First steps to define murine amniotic fluid stem cell microenvironment. Sci Rep 2016;6:37080.

23. Mohyeldin A, Garzón-Muvdi T, Quiñones-Hinojosa A. Oxygen in stem cell biology: A critical component of the stem cell niche. Cell Stem Cell 2010;7:150-161.

24. Bizzarri A, Koehler H, Cajlakovic M, et al. Continuous oxygen monitoring in subcutaneous adipose tissue using microdialysis. Anal Chim Acta 2006;573-574:48-56.

25. Harrison JS, Rameshwar P, Chang V, Bandari P. Oxygen saturation in the bone marrow of healthy volunteers. Blood 2002;99:394.

26. Spencer JA, Ferraro F, Roussakis E, et al. Direct measurement of local oxygen concentration in the bone marrow of live animals. Nature 2014;508:269-273.

27. Walter D, Lier A, Geiselhart A, et al. Exit from dormancy provokes DNA-damage-induced attrition in haematopoietic stem cells. Nature 2015;520:549-552.

28. Wilson A, Laurenti E, Oser G, et al. Hematopoietic stem cells reversibly switch from dormancy to self-renewal during homeostasis and repair. Cell 2008;135:1118-1129.

29. Zhou D, Shao L, Spitz DR. Reactive oxygen species in normal and tumor stem cells. Adv Cancer Res 2014;122: $1-67$.

30. Morrison SJ, Kimble J. Asymmetric and symmetric stemcell divisions in development and cancer. Nature 2006; 441:1068-1074.

31. Genbacev O, Zhou Y, Ludlow JW, Fisher SJ. Regulation of human placental development by oxygen tension. Science 1997;277:1669-1672.

32. Schofield CJ, Ratcliffe PJ. Signalling hypoxia by HIF hydroxylases. Biochem Biophys Res Commun 2005;338: 617-626.

33. Berra E, Benizri E, Ginouvès A, Volmat V, Roux D, Pouysségur J. HIF prolyl-hydroxylase 2 is the key oxygen sensor setting low steady-state levels of HIF-1alpha in normoxia. EMBO J 2003;22:4082-4090.

34. Berra E, Ginouvès A, Pouysségur J. The hypoxiainducible-factor hydroxylases bring fresh air into hypoxia signalling. EMBO Rep 2006;7:41-45.

35. Semenza GL. Hydroxylation of HIF-1: Oxygen sensing at the molecular level. Physiology (Bethesda) 2004;19:176-182.

36. Covello KL, Kehler J, Yu H, et al. HIF-2alpha regulates Oct-4: Effects of hypoxia on stem cell function, embryonic development, and tumor growth. Genes Dev 2006;20: 557-570.

37. Sterneckert J, Höing S, Schöler HR. Concise review: Oct4 and more: The reprogramming expressway. Stem Cells 2012;30:15-21.

38. Boulais PE, Frenette PS. Making sense of hematopoietic stem cell niches. Blood 2015;125:2621-2629.

39. Simsek T, Kocabas F, Zheng J, et al. The distinct metabolic profile of hematopoietic stem cells reflects their location in a hypoxic niche. Cell Stem Cell 2010;7:380-390. 
40. Pattappa G, Thorpe SD, Jegard NC, Heywood HK, de Bruijn JD, Lee DA. Continuous and uninterrupted oxygen tension influences the colony formation and oxidative metabolism of human mesenchymal stem cells. Tissue Eng Part C Methods 2013;19:68-79.

41. Kobayashi CI, Suda T. Regulation of reactive oxygen species in stem cells and cancer stem cells. J Cell Physiol 2012;227:421-430.

42. Shyh-Chang N, Daley GQ, Cantley LC. Stem cell metabolism in tissue development and aging. Development 2013;140:2535-2547.

43. Jung MS, Jin DH, Chae HD, et al. Bcl-xL and E1B-19K proteins inhibit p53-induced irreversible growth arrest and senescence by preventing reactive oxygen speciesdependent p38 activation. J Biol Chem 2004;279:1776517771.

44. Macip S, Igarashi M, Fang L, et al. Inhibition of p21mediated ROS accumulation can rescue p21-induced senescence. EMBO J 2002;21:2180-2188.

45. Tothova Z, Kollipara R, Huntly BJ, et al. FoxOs are critical mediators of hematopoietic stem cell resistance to physiologic oxidative stress. Cell 2007;128:325-339.

46. Oh J, Lee YD, Wagers AJ. Stem cell aging: Mechanisms, regulators and therapeutic opportunities. Nat Med 2014; 20:870-880.

47. Shao L, Li H, Pazhanisamy SK, Meng A, Wang Y, Zhou D. Reactive oxygen species and hematopoietic stem cell senescence. Int J Hematol 2011;94:24-32.

48. Ong ALC, Ramasamy TS. Role of Sirtuin1-p53 regulatory axis in aging, cancer and cellular reprogramming. Ageing Res Rev 2018;43:64-80.

49. Brown K, Xie S, Qiu X, et al. SIRT3 reverses agingassociated degeneration. Cell Rep 2013;3:319-327.

50. Kumar S, Geiger H. HSC niche biology and HSC expansion ex vivo. Trends Mol Med 2017;23:799-819.

51. Cruz FF, Rocco PR. Hypoxic preconditioning enhances mesenchymal stromal cell lung repair capacity. Stem Cell Res Ther 2015;6:130.

52. Lan YW, Choo KB, Chen CM, et al. Hypoxiapreconditioned mesenchymal stem cells attenuate bleomycin-induced pulmonary fibrosis. Stem Cell Res Ther 2015;6:97.

53. Wakai T, Narasimhan $\mathrm{P}$, Sakata $\mathrm{H}$, et al. Hypoxic preconditioning enhances neural stem cell transplantation therapy after intracerebral hemorrhage in mice. J Cereb Blood Flow Metab 2016;36:2134-2145.

54. Basciano L, Nemos C, Foliguet B, et al. Long term culture of mesenchymal stem cells in hypoxia promotes a genetic program maintaining their undifferentiated and multipotent status. BMC Cell Biol 2011;12:12.

55. Grayson WL, Zhao F, Bunnell B, Ma T. Hypoxia enhances proliferation and tissue formation of human mesenchymal stem cells. Biochem Biophys Res Commun 2007;358:948-953.

56. Li TS, Marbán E. Physiological levels of reactive oxygen species are required to maintain genomic stability in stem cells. Stem Cells 2010;28:1178-1185.

57. Forsyth NR, Musio A, Vezzoni P, Simpson AH, Noble BS, McWhir J. Physiologic oxygen enhances human embryonic stem cell clonal recovery and reduces chromosomal abnormalities. Cloning Stem Cells 2006;8: $16-23$.

58. Kim DS, Ko YJ, Lee MW, et al. Effect of low oxygen tension on the biological characteristics of human bone marrow mesenchymal stem cells. Cell Stress Chaperones 2016;21:1089-1099.

59. Ejtehadifar M, Shamsasenjan K, Movassaghpour A, et al. The effect of hypoxia on mesenchymal stem cell biology. Adv Pharm Bull 2015;5:141-149.

60. Pezzi A, Amorin B, Laureano Á, et al. Effects of hypoxia in long-term in vitro expansion of human bone marrow derived mesenchymal stem cells. J Cell Biochem 2017; 118:3072-3079.

61. Holzwarth C, Vaegler M, Gieseke F, et al. Low physiologic oxygen tensions reduce proliferation and differentiation of human multipotent mesenchymal stromal cells. BMC Cell Biol 2010;11:11.

62. Salim A, Nacamuli RP, Morgan EF, Giaccia AJ, Longaker MT. Transient changes in oxygen tension inhibit osteogenic differentiation and Runx2 expression in osteoblasts. J Biol Chem 2004;279:40007-40016.

63. Lennon DP, Edmison JM, Caplan AI. Cultivation of rat marrow-derived mesenchymal stem cells in reduced oxygen tension: Effects on in vitro and in vivo osteochondrogenesis. J Cell Physiol 2001;187:345-355.

64. Malladi P, Xu Y, Chiou M, Giaccia AJ, Longaker MT. Effect of reduced oxygen tension on chondrogenesis and osteogenesis in adipose-derived mesenchymal cells. Am J Physiol Cell Physiol 2006;290:C1139-C1146.

65. Choudhery MS, Badowski M, Muise A, Pierce J, Harris DT. Donor age negatively impacts adipose tissue-derived mesenchymal stem cell expansion and differentiation. J Transl Med 2014;12:8.

66. El Alami M, Viña-Almunia J, Gambini J, et al. Activation of $\mathrm{p} 38, \mathrm{p} 21$, and NRF-2 mediates decreased proliferation of human dental pulp stem cells cultured under $21 \% \mathrm{O} 2$. Stem Cell Rep 2014;3:566-573.

67. Brown GC, Borutaite V. There is no evidence that mitochondria are the main source of reactive oxygen species in mammalian cells. Mitochondrion 2012;12:1-4.

68. Dröge W. Free radicals in the physiological control of cell function. Physiol Rev 2002;82:47-95.

69. Case J, Ingram DA, Haneline LS. Oxidative stress impairs endothelial progenitor cell function. Antioxid Redox Signal 2008;10:1895-1907.

70. Ito K, Hirao A, Arai F, et al. Reactive oxygen species act through p38 MAPK to limit the lifespan of hematopoietic stem cells. Nat Med 2006;12:446-451.

71. Ushio-Fukai M, Rehman J. Redox and metabolic regulation of stem/progenitor cells and their niche. Antioxid Redox Signal 2014;21:1587-1590.

72. Naka K, Muraguchi T, Hoshii T, Hirao A. Regulation of reactive oxygen species and genomic stability in hematopoietic stem cells. Antioxid Redox Signal 2008;10: 1883-1894.

73. Jang YY, Sharkis SJ. A low level of reactive oxygen species selects for primitive hematopoietic stem cells that may reside in the low-oxygenic niche. Blood 2007;110: 3056-3063.

74. Starkov AA. The role of mitochondria in reactive oxygen species metabolism and signaling. Ann N Y Acad Sci 2008;1147:37-52.

75. Nordzieke DE, Medraño-Fernandez I. The plasma membrane: A platform for intra- and intercellular redox signaling. Antioxidants (Basel) 2018;7.

76. Jezek P, Hlavatá L. Mitochondria in homeostasis of reactive oxygen species in cell, tissues, and organism. Int J Biochem Cell Biol 2005;37:2478-2503. 
77. Del Río LA, López-Huertas E. ROS Generation in peroxisomes and its role in cell signaling. Plant Cell Physiol 2016;57:1364-1376.

78. Ivanov I, Heydeck D, Hofheinz K, et al. Molecular enzymology of lipoxygenases. Arch Biochem Biophys 2010; 503:161-174

79. Ben-Mahdi MH, Dang PM, Gougerot-Pocidalo MA, O’Dowd Y, El-Benna J, Pasquier C. Xanthine oxidasederived ros display a biphasic effect on endothelial cells adhesion and FAK phosphorylation. Oxid Med Cell Longev 2016;2016:9346242.

80. Piccoli C, Ria R, Scrima R, et al. Characterization of mitochondrial and extra-mitochondrial oxygen consuming reactions in human hematopoietic stem cells. Novel evidence of the occurrence of $\mathrm{NAD}(\mathrm{P}) \mathrm{H}$ oxidase activity. J Biol Chem 2005;280:26467-26476.

81. Drehmer DL, de Aguiar AM, Brandt AP, et al. Metabolic switches during the first steps of adipogenic stem cells differentiation. Stem Cell Res 2016;17:413-421.

82. Piccoli C, D'Aprile A, Scrima R, et al. Role of reactive oxygen species as signal molecules in the precommitment phase of adult stem cells. Ital J Biochem 2007;56:7.

83. Wang Y, Liu L, Pazhanisamy SK, Li H, Meng A, Zhou D. Total body irradiation causes residual bone marrow injury by induction of persistent oxidative stress in murine hematopoietic stem cells. Free Radic Biol Med 2010;48: 348-356.

84. Yamaguchi M, Kashiwakura I. Role of reactive oxygen species in the radiation response of human hematopoietic stem/progenitor cells. PLoS One 2013;8:e70503.

85. Liu J, Cao L, Chen J, et al. Bmi1 regulates mitochondrial function and the DNA damage response pathway. Nature 2009;459:387-392.

86. Chen C, Liu Y, Liu R, Ikenoue T, Guan KL, Zheng P. TSC-mTOR maintains quiescence and function of hematopoietic stem cells by repressing mitochondrial biogenesis and reactive oxygen species. J Exp Med 2008;205: 2397-2408

87. Wong JL, Wessel GM. Reactive oxygen species and Udx 1 during early sea urchin development. Dev Biol 2005;288: 317-333.

88. Schmelter M, Ateghang B, Helmig S, Wartenberg M, Sauer H. Embryonic stem cells utilize reactive oxygen species as transducers of mechanical strain-induced cardiovascular differentiation. FASEB J 2006;20:1182-1184.

89. Cho YM, Kwon S, Pak YK, et al. Dynamic changes in mitochondrial biogenesis and antioxidant enzymes during the spontaneous differentiation of human embryonic stem cells. Biochem Biophys Res Commun 2006;348:14721478.

90. Sheshadri P, Kumar A. Managing odds in stem cells: Insights into the role of mitochondrial antioxidant enzyme MnSOD. Free Radic Res 2016;50:570-584.

91. Klein D, Steens J, Wiesemann A, et al. Mesenchymal stem cell therapy protects lungs from radiation-induced endothelial cell loss by restoring superoxide dismutase 1 expression. Antioxid Redox Signal 2017;26:563-582.

92. Sundaramoorthy P, Wang Q, Zheng Z, et al. Thioredoxin mitigates radiation-induced hematopoietic stem cell injury in mice. Stem Cell Res Ther 2017;8:263.

93. Olivares-Vicente M, Barrajon-Catalan E, Herranz-Lopez $\mathrm{M}$, et al. Plant-derived polyphenols in human health:
Biological activity, metabolites and putative molecular targets. Curr Drug Metab 2018;19:351-369.

94. Wang Y, Li M, Xu X, Song M, Tao H, Bai Y. Green tea epigallocatechin-3-gallate (EGCG) promotes neural progenitor cell proliferation and sonic hedgehog pathway activation during adult hippocampal neurogenesis. Mol Nutr Food Res 2012;56:1292-1303.

95. Zhang Y, He Q, Dong J, Jia Z, Hao F, Shan C. Effects of epigallocatechin-3-gallate on proliferation and differentiation of mouse cochlear neural stem cells: Involvement of PI3K/Akt signaling pathway. Eur J Pharm Sci 2016;88: 267-273.

96. Angeloni C, Hrelia S. Quercetin reduces inflammatory responses in LPS-stimulated cardiomyoblasts. Oxid Med Cell Longev 2012;2012:837104.

97. Baral S, Pariyar R, Kim J, Lee HS, Seo J. Quercetin-3-Oglucuronide promotes the proliferation and migration of neural stem cells. Neurobiol Aging 2017;52:39-52.

98. Kim SY, Jeong HC, Hong SK, Lee MO, Cho SJ, Cha HJ. Quercetin induced ROS production triggers mitochondrial cell death of human embryonic stem cells. Oncotarget 2017;8:64964-64973.

99. Nichols M, Zhang J, Polster BM, et al. Synergistic neuroprotection by epicatechin and quercetin: Activation of convergent mitochondrial signaling pathways. Neuroscience 2015;308:75-94.

100. Correia M, Rodrigues AS, Perestrelo T, et al. Different concentrations of kaempferol distinctly modulate murine embryonic stem cell function. Food Chem Toxicol 2016; $87: 148-156$.

101. Lee CH, Jeong TS, Choi YK, et al. Anti-atherogenic effect of citrus flavonoids, naringin and naringenin, associated with hepatic ACAT and aortic VCAM-1 and MCP-1 in high cholesterol-fed rabbits. Biochem Biophys Res Commun 2001;284:681-688.

102. Zhang P, Dai KR, Yan SG, et al. Effects of naringin on the proliferation and osteogenic differentiation of human bone mesenchymal stem cell. Eur J Pharmacol 2009;607:1-5.

103. Liu M, Li Y, Yang ST. Effects of naringin on the proliferation and osteogenic differentiation of human amniotic fluid-derived stem cells. J Tissue Eng Regen Med 2017; 11:276-284.

104. Zhong S, Ge J, Yu JY. Icariin prevents cytokine-induced $\beta$-cell death by inhibiting NF- $\kappa$ B signaling. Exp Ther Med 2018;16:2756-2762.

105. Fan JJ, Cao LG, Wu T, et al. The dose-effect of icariin on the proliferation and osteogenic differentiation of human bone mesenchymal stem cells. Molecules 2011;16:10123-10133.

106. Huang JH, Cai WJ, Zhang XM, Shen ZY. Icariin promotes self-renewal of neural stem cells: An involvement of extracellular regulated kinase signaling pathway. Chin J Integr Med 2014;20:107-115.

107. Yang P, Guan YQ, Li YL, Zhang L, Li L. Icariin promotes cell proliferation and regulates gene expression in human neural stem cells in vitro. Mol Med Rep 2016;14:13161322.

108. Fu X, Li S, Zhou S, Wu Q, Jin F, Shi J. Stimulatory effect of icariin on the proliferation of neural stem cells from rat hippocampus. BMC Complement Altern Med 2018;18:34.

109. Qin S, Zhou W, Liu S, Chen P, Wu H. Icariin stimulates the proliferation of rat bone mesenchymal stem cells via ERK and p38 MAPK signaling. Int J Clin Exp Med 2015; 8:7125-7133. 
110. Ye Y, Jing X, Li N, Wu Y, Li B, Xu T. Icariin promotes proliferation and osteogenic differentiation of rat adiposederived stem cells by activating the RhoA-TAZ signaling pathway. Biomed Pharmacother 2017;88:384-394.

111. Chen S, Deng X, Ma K, et al. Icariin improves the viability and function of cryopreserved human nucleus pulposus-derived mesenchymal stem cells. Oxid Med Cell Longev 2018;2018:3459612.

112. Tsang WP, Zhang F, He Q, et al. Icaritin enhances mESC self-renewal through upregulating core pluripotency transcription factors mediated by ER $\alpha$. Sci Rep 2017;7: 40894.

113. Lim RZL, Li L, Yong EL, Chew N. STAT-3 regulation of CXCR4 is necessary for the prenylflavonoid Icaritin to enhance mesenchymal stem cell proliferation, migration and osteogenic differentiation. Biochim Biophys Acta Gen Subj 2018;1862:1680-1692.

114. Deldar Y, Zarghami F, Pilehvar-Soltanahmadi Y, Dadashpour M, Zarghami N. Antioxidant effects of chrysinloaded electrospun nanofibrous mats on proliferation and stemness preservation of human adipose-derived stem cells. Cell Tissue Bank 2017;18:475-487.

115. Menon AH, Soundarya SP, Sanjay V, Chandran SV, Balagangadharan K, Selvamurugan N. Sustained release of chrysin from chitosan-based scaffolds promotes mesenchymal stem cell proliferation and osteoblast differentiation. Carbohydr Polym 2018;195:356-367.

116. Han D, Kim HJ, Choi HY, et al. 3,2'-Dihydroxyflavonetreated pluripotent stem cells show enhanced proliferation, pluripotency marker expression, and neuroprotective properties. Cell Transplant 2015;24:1511-1532.

117. Kuzu M, Kandemir FM, Yildirim S, Kucukler S, Caglayan C, Turk E. Morin attenuates doxorubicin-induced heart and brain damage by reducing oxidative stress, inflammation and apoptosis. Biomed Pharmacother 2018;106: 443-453.

118. He Q, Jia Z, Zhang Y, Ren X. Morin hydrate promotes inner ear neural stem cell survival and differentiation and protects cochlea against neuronal hearing loss. J Cell Mol Med 2017;21:600-608

119. Burns J, Yokota T, Ashihara H, Lean ME, Crozier A. Plant foods and herbal sources of resveratrol. J Agric Food Chem 2002;50:3337-3340.

120. Song LH, Pan W, Yu YH, Quarles LD, Zhou HH, Xiao ZS. Resveratrol prevents CsA inhibition of proliferation and osteoblastic differentiation of mouse bone marrowderived mesenchymal stem cells through an ER/NO/cGMP pathway. Toxicol In Vitro 2006;20:915-922.

121. Dai Z, Li Y, Quarles LD, et al. Resveratrol enhances proliferation and osteoblastic differentiation in human mesenchymal stem cells via ER-dependent ERK1/2 activation. Phytomedicine 2007;14:806-814.

122. Peltz L, Gomez J, Marquez M, et al. Resveratrol exerts dosage and duration dependent effect on human mesenchymal stem cell development. PLoS One 2012;7:e37162.

123. Li N, Du Z, Shen Q, et al. Resveratrol enhances selfrenewal of mouse embryonic stem cells. J Cell Biochem 2017;118:1928-1935.

124. Safaeinejad Z, Nabiuni M, Peymani M, Ghaedi K, NasrEsfahani MH, Baharvand $\mathrm{H}$. Resveratrol promotes human embryonic stem cells self-renewal by targeting SIRT1ERK signaling pathway. Eur J Cell Biol 2017;96:665672 .
125. Jiang LH, Yang NY, Yuan XL, et al. Daucosterol promotes the proliferation of neural stem cells. J Steroid Biochem Mol Biol 2014;140:90-99.

126. Kim R, Lee S, Lee CY, et al. Salvia miltiorrhiza enhances the survival of mesenchymal stem cells under ischemic conditions. J Pharm Pharmacol 2018;70:1228-1241.

127. Zhuang P, Zhang Y, Cui G, et al. Direct stimulation of adult neural stem/progenitor cells in vitro and neurogenesis in vivo by salvianolic acid B. PLoS One 2012;7: e35636.

128. Angeloni C, Malaguti M, Barbalace MC, Hrelia S. Bioactivity of olive oil phenols in neuroprotection. Int $\mathbf{J}$ Mol Sci 2017;18.

129. Ji ST, Kim YJ, Jung SY, et al. Oleuropein attenuates hydrogen peroxide-induced autophagic cell death in human adipose-derived stem cells. Biochem Biophys Res Commun 2018;499:675-680.

130. Typek R, Dawidowicz AL, Wianowska D, Bernacik K, Stankevič M, Gil M. Formation of aqueous and alcoholic adducts of curcumin during its extraction. Food Chem 2019;276:101-109.

131. Kim SJ, Son TG, Park HR, et al. Curcumin stimulates proliferation of embryonic neural progenitor cells and neurogenesis in the adult hippocampus. J Biol Chem 2008;283:14497-14505.

132. Galasso C, Orefice I, Pellone P, et al. On the neuroprotective role of astaxanthin: New perspectives? Mar Drugs 2018;16.

133. Kidd P. Astaxanthin, cell membrane nutrient with diverse clinical benefits and anti-aging potential. Altern Med Rev 2011;16:355-364.

134. Kim JH, Nam SW, Kim BW, et al. Astaxanthin improves stem cell potency via an increase in the proliferation of neural progenitor cells. Int J Mol Sci 2010;11:5109-5119.

135. Fontenelle RO, Morais SM, Brito EH, et al. Chemical composition, toxicological aspects and antifungal activity of essential oil from Lippia sidoides Cham. J Antimicrob Chemother 2007;59:934-940.

136. Brito FN, Vendramin FS, Lopes CTA, et al. Proliferation of human adipose tissue-derived stem cells stimulated by oil rich in thymol of Lippia origanoides. Acta Cir Bras 2018;33:431-438.

137. Nalewajko-Sieliwoniuk E, Malejko J, Twarowska P, Timoszuk M, Nazaruk J. Postcolumn determination of polyphenolic antioxidants in Cirsium vulgare (Savi) Ten. extracts. J Sep Sci 2017;40:3830-3838.

138. Abdanipour A, Noori-Zadeh A, Mesbah-Namin SA, Bakhtiyari S, Nejatbakhsh R, Anarkooli IJ. Di-(2ethylhexyl) phthalate-induced hippocampus-derived neural stem cells proliferation. Cell J 2017;19:166-172.

139. Hirunpanich V, Utaipat A, Morales NP, et al. Hypocholesterolemic and antioxidant effects of aqueous extracts from the dried calyx of Hibiscus sabdariffa L. in hypercholesterolemic rats. J Ethnopharmacol 2006;103:252260.

140. Micucci M, Malaguti M, Toschi TG, et al. Cardiac and vascular synergic protective effect of Olea europea L. Leaves and Hibiscus sabdariffa L. Flower Extracts. Oxid Med Cell Longev 2015;2015:318125.

141. Abdul Hamid Z, Lin Lin WH, Abdalla BJ, et al. The role of Hibiscus sabdariffa L. (Roselle) in maintenance of ex vivo murine bone marrow-derived hematopoietic stem cells. ScientificWorldJournal 2014;2014:258192. 
142. Huang XF, Yuan SJ, Yang C. Effects of total flavonoids from Drynaria fortunei on the proliferation and osteogenic differentiation of rat dental pulp stem cells. Mol Med Rep 2012;6:547-552.

143. Yao R, Zhang L, Li X, Li L. Effects of Epimedium flavonoids on proliferation and differentiation of neural stem cells in vitro. Neurol Res 2010;32:736-742.

144. Zaidi SNF, Mahboob T. Prevention of liver cirrhosis by Silymarin. Pak J Pharm Sci 2017;30:1203-1211.

145. Ahmadi-Ashtiani H, Allameh A, Rastegar H, Soleimani M, Barkhordari E. Inhibition of cyclooxygenase-2 and inducible nitric oxide synthase by silymarin in proliferating mesenchymal stem cells: Comparison with glutathione modifiers. J Nat Med 2012;66:85-94.

146. Bickford PC, Tan J, Shytle RD, Sanberg CD, El-Badri N, Sanberg PR. Nutraceuticals synergistically promote proliferation of human stem cells. Stem Cells Dev 2006;15: 118-123.

147. Marrazzo P, Angeloni C, Freschi M, et al. Combination of epigallocatechin gallate and sulforaphane counteracts in vitro oxidative stress and delays stemness loss of am- niotic fluid stem cells. Oxid Med Cell Longev 2018: 5263985.

148. Luo L, Kawakatsu M, Guo CW, et al. Effects of antioxidants on the quality and genomic stability of induced pluripotent stem cells. Sci Rep 2014;4:3779.

149. Noon AT, Goodarzi AA. 53BP1-mediated DNA double strand break repair: Insert bad pun here. DNA Repair (Amst) 2011;10:1071-1076.

150. Kitagawa R, Kastan MB. The ATM-dependent DNA damage signaling pathway. Cold Spring Harb Symp Quant Biol 2005;70:99-109.

Address correspondence to:

Cristina Angeloni

School of Pharmacy

University of Camerino

Via Gentile III da Varano

Camerino 62032

Italy

E-mail: cristina.angeloni@unicam.it 